\title{
Cephaloglycin Anhydrous
}

National Cancer Institute

\section{Source}

National Cancer Institute. Cephaloglycin Anhydrous. NCI Thesaurus. Code C76593.

The anhydrous form of cephalog lycin, a semisynthetic first-generation cephalosporin with antibacterial activity. Cephaloglycin binds to and inactivates penicillin-binding proteins (PBPs) located on the inner membrane of the bacterial cell wall. PBPs are enzymes involved in the terminal stages of assembling the bacterial cell wall and in reshaping the cell wall during growth and division. Inactivation of PBPs interferes with the cross-linkage of peptidoglycan chains necessary for bacterial cell wall strength and rigidity. This results in the weakening of the bacterial cell wall and causes cell lysis. 